\title{
On Maggie’s Feminist Thoughts in The Mill on the Floss
}

\author{
LIU Xi, MA Wen-ying \\ Changchun University, Changchun, China
}

\begin{abstract}
George Eliot(1819-1880), is one of the most highly praised novelists in the literary world in the 19th century because of her unique position in English literature. She wrote a large quantity of works of the highest merit and of far-reaching influence. Her attitude towards feminism has aroused wide attention and has been discussed hotly among feminist critics in different countries. The Mill on the Floss, which first appeared in1860, is regarded as the most excellent autobiographical novel of Eliot. The ideology of male power in the patriarchal society during the Victorian Era is internalized in people's heart, which brings huge influence on Maggie’s female mental state. This paper aims to discuss the causes of Maggie's feminist thoughts and manifestation of her feminism, thus, the influence upon women in her times. The paper concludes that Eliot was a great female author full of pioneering feminist thought from the example given by Maggie in The Mill on the Floss.
\end{abstract}

Keywords: Victorian era, feminist thought, patriarchal society, pursuit

\section{Introduction}

George Eliot (1819-1880), pen name of Mary Ann Evans, was an English novelist, journalist, and one of the leading writers in Victorian era. Among the seven novels she wrote, most of them are set in provincial England and known for their realism and psychological insight. In Victorian era, female authors were published under their own names, but Eliot wanted to escape the stereotype of women only writing carefree romances so that she used a male pen name to ensure her works would be taken seriously.

The Mill on the Floss is Eliot's excellent autobiographical novel. The novel spans a period of 10 to 15 years and details to show the lives of Tom and Maggie Tulliver, siblings growing up at Dorlcote Mill on the River Floss in Lincolnshire, England. Maggie Tulliver is the young Eliot herself. The story begins when Maggie was nine years old. Her relationship with her older brother Tom, her romantic relationships with Philip Wakem, a hunchbacked, intellectual friend, and with Stephen Guest, a lively young socialite, constituted the most important narrative thread. Tom and Maggie had a close but complex connection, which continued throughout the novel. Their relationship was colored by Maggie's desire to regain the unconditional love her father gave before his death. Tom's pragmatic and reserved nature had a conflict with Maggie's idealism and fervor for intellectual gains and experience. Various family crises, including bankruptcy, served to both intensify Tom's and Maggie's differences and foiled their love for each other. Maggie's brief exile ended when the river flooded. Having struggled through the water in a boat to find Tom at the old mill, she set out with him to rescue Lucy's family.

LIU Xi, master, lecturer, School of Foreign Languages, Changchun University.

MA Wen-ying, Ph.D., associate professor, School of Foreign Languages, Changchun University. 
Tenderly, the brother and sister were reconciled from all past differences. When their boat capsized, the two were drown in an embrace.

This paper aims to have a feminist reading of the novel to show how Eliot reveals her feminist consciousness through her disclosure and criticism on the discrimination and oppression of women in this novel. Furthermore, the paper probes into Maggie's struggle with her brother and her society, one is, to some extent, able to understand her attitude toward feminism. The paper concludes that Maggie is a pioneering woman warrior in Victorian era, Who tries to win her equal economic and social status with men in a variety of ways in a man-dominating world.

\section{Causes of Maggie's Feminist Thoughts}

Women's low social position was the main cause of Maggie's feminist thought. They, as a social group, were looked down upon by men - the ruler of British law. As they did not possess political rights, their voice for equality with men failed to be heard and they still acted as the servants of men.

In Maggie's early childhood, she was despised by the people around her, the Dosons in particular. Her mother, She regarded Maggie as “a mistake of nature” because Maggie did not inherit her long hair and graceful behavior. Maggie yearned for all knowledge and music, which were beautiful and glad. Maggie thought highly of education and intelligence and her support for education could provide a feminist with some active experiences.

However, her father, the only person that loved her, supposed that her intelligence would bring her trouble in the future. Under no circumstances did he doubt of his daughter's potentiality for learning. Yet, he would rather send his poor son to learn what he disgusted and feared. Later, thanks to her aunt Pullet who afforded her insignificant tuition in a distant boarding school, Maggie finally obtained the opportunity to receive some meager education. Even that was suspended when family distress inflicted on everyone. After she came home, her contradictory impulse to seek knowledge and colorful spiritual life on the one hand, and to accept the dismal reality on the other, failed to be calmed down so that she was disappointed to see that her education could not guide her through inexorable pain.

In the world overruled by men, men and women were in every aspect unequal.

Men were seen as superior while women inferior; Men were seen as active while women passive. Men were strong while women weak; Men possessed the power to shape the world, the woman emotion and motherly love; hence men were dominative, women submissive (Karen, 1994).

In love and marriage, women were still expected to subordinate their emotions and life's purposes to those of men's. Masculine power seemed always ready to manipulate women's thoughts and behavior. Women were usually passive in love and marriage. When they were single, they were merely taken as commodities in the marriage market. Women were looked down upon as commodities for exchange on the marriage market, waiting passively for buyers.

A man expects his wife to be pretty, but not to a maddening extent. A man likes his wife to be accomplished, gentle, affectionate, and not stupid; and Lucy had all these qualifications. Stephen was aware that he had sense and independence enough to choose his wife who was likely to make him happy. He meant to choose Lucy. "She was a little darling, and exactly the sort of women he had always most admired”. (Barbara, 1987, p.495)

However, Maggie failed be sold at a good price in that she was too bright and intelligent. Feminine power 
was eternally mediated by masculine force on the altar of men. Maggie was just a simple example of women at her time who was facing a dilemma that on one hand, she dreamed of her own right to choose who she fancied, while on the other hand, she was given almost no right to make any decision. Actually, most of the Victorian women like Maggie had be obedient to their husbands. They had to be housewives, caring only for their husbands and children. Thus those originally ambitious women had to give up their aspirations and condescend to perform wifely functions properly. Being oppressed by men for a long time, Maggie could not hold back the strong desire to be equal with men so that the sparks of feminist thoughts began to burst forth in her mind.

\section{Maggie's Pursuit of Education Equality}

Maggie was a rebellious and unconventional woman. Her character was viewed as a threat to the dominant ideology, in which she made every effort to gain peace, power, and acceptance but in vain.

One of the social inequality in Victorian era between men and women were reflected in education, which was one of women's greatest obstacles to fulfill their dreams and to achieve success in their undertakings. Women's fate was still determined by the prevailing assumptions about gender in the society. They maintained that, like "the lower races", women had smaller and less efficient brain, less complex nerve development, and less susceptibility to certain disease than men. Under the influence of traditional ideology, women were deprived of educational right. It was known to Victorian people that education was one way which was advantageous for social progress and personal development. It was the prevalent belief that men belonged to the workplace whereas women belonged to home. Thus, boys must be educated to make great achievements in the workplace, while girls merely needed to know how to be a good housewife. It was thought that women's position was carried out through men not through the efforts of their own. If a woman wanted her living conditions to be changed completely, her first task was to wake up her consciousness by means of education. Women in the Victorian period were thought as not fit for mental work so that only few women went to public school while men were sent to learn knowledge.

In Maggie's whole life, she never gave up knowledge, whether in her childhood, in her family's downfall, or at last moment of her life. What's more, she tried to take advantage of knowledge to achieve different goals in her different life periods. In her early years, she had close relations with books. She was always found to sit in a corner with a book in her hand. Little Maggie read widely all the books she could get including the novels written by Daniel Defoe, John Bunyan, and Aesop’s fable. When she saw the bookcases in the study, exclaiming: "How I should like to have as many books as that!” (Eliot,1994, p.146) Although she was quick-witted to knowledge, it was considered not a good thing for a girl and would definitely lead to trouble. In order to protest against the authority and prove the advantages of a girl's mastery of knowledge, Maggie revealed an irrepressible impulse to be respected by them. What she did first was to attempt to impress Mr. Riley with her intelligence. After Maggie's enthusiastic explanation "with triumphant excitement: she thought Mr. Riley would have a respect for her" (Eliot,1994, p.154). On the contrary, she had got unexpected judgment. As a result, to her great disappointment, her attempt to win respect from men was crushed so that "Maggie looked hurt and discouraged...”(Eliot,1994, p.166). Nevertheless, she would never stop her search for knowledge.

In her school age, Maggie claimed her strong opposition to the traditional point of view that women's intellectual ability was inferior to that of men and women should be excluded from "masculine studies". Maggie 
would not shake her determination to protest against the prejudiced patriarchal society and to be an independent person. Even in her womanhood, Maggie considered knowledge as an effective weapon to gain mental equality with men of her age. Driven by the pioneering thought, Maggie’s pursuit for education never came to a halt. Such a pursuit was a concrete example of her feminist thought.

\section{Maggie's Pursuit of Economic Independence}

In the novel, from the beginning to the end, Maggie made all her efforts to display her intellectual ability superior to men, thus, she suffered a lot in this aspect. In the course of her furious struggle against men, as a woman in masculine world, Maggie concluded that the only way to obtain equality and escape men's limitation was to be independent economically. So she tried to help her brother Tom to support their family when they were in the downfall. Furthermore, she resolved to support herself when she was deserted by Tom. After her father's death, Maggie returned on vacation from her dreary situation in a school. The vocation of the governess, which was regarded as the last refuge of despair in the 19th century, was a job Maggie had taken in order to be economically independent. In fact, Maggie regarded economic independence as the last means to acquire the respect of others. Living in the age in which women were believed to be inferior to men, Maggie would prove her life value as a woman and challenge to the world. Unlike other women who were pleased to be "angels at home", the relation between Maggie and Tom stood for the conflict between dream world and real life, and between women's desire for independence and men's patriarchy. In dealing with her relation with Tom, Maggie also chose the way of seeming submission in which she could achieve her goal and win her brother's love. For example, threatened by Tom's ultimatum that she chose him and Philip, Maggie submitted to Tom. Actually Maggie used her brother's force to give up Philip with whom she didn't fall in love. In addition, in order to free her from the oppression of narrow outward conditions, she must free herself from those conditions through her tolerance. Meanwhile, Maggie had found that women were intrinsically more emotional and more capable of love than men, so only by repressing the larger capacity for love could women gain power in the conflict with men. Therefore, "Maggie's obstinacy was the only way to remain independent and to maintain her own desires and beliefs in the face of coercion” (Gordon, 1970, p.92). Maggie got in touch with some distinguished persons in science and literature, her ambition as a woman was discriminated and prejudiced by the prevailing ideology of that society.

Maggie had ambiguous relationship with two men: Philips and Stephen. Though she was criticized by her brother and the secular people in her village, she did not change her mind to appeal the conventional ideology. Maggie's elopement with Stephen could be perceived as her escape from the tension of society and her efforts to seek for her love and marital independence. Maggie claimed to the world that women had their own rights to pursue their happy life. Moreover, she attempted to explore an appropriate way for men and women in order to reach an idealized harmonious society they live. Maggie safeguarded her economic and marital independence firmly not only in principle, but also in practice. She experienced painful process of trying to gain economic and marital independence in Victorian families. She conveyed her unconventional and ambitious idealism—genuine independence.

In breaking the old traditional marriage shackles to look for her own emotional world, she was courageous enough to endure a furious depression and reproach from the conservative society and her relatives. Namely, 
Maggie challenged to the prevailing gender assumptions and criticism of woman's existing conditions and the suppression of woman's self.

\section{Conclusion}

Maggie made painstaking efforts to obtain her rights in the aspect and her failure resulted in profound meaning in her times. Maggie supported feminist reforms in marriage and divorce laws, endorsed women's social emancipation and recommended better education for women. Maggie's attitude towards marriage reforms during the 1840s and 1850s reflected her feminist thought to pursue equality between men and women. For another, Maggie's attitude towards feminism also reflected her limitations as a woman living in a patriarchal society. In general, living in the patriarchal Victorian England, Maggie was inevitably influenced by the prevailing gender assumptions, which influenced her attitude towards feminism. However, in the meanwhile, Maggie indicated that larger educational and social changes were necessary in order to cultivate the higher sensibilities of women and to allow them to pursue a life of independent study that would provide a sustaining moral purpose for their lives. From this perspective, Eliot was a great female author full of pioneering feminist thought from the example given by Maggie in The Mill on the Floss.

\section{References}

Alison, B. (1992). Greatness engendered: George Eliot and Virginia Woolf. New York: Comell University Press. April, L. (2012). The Cambridge introduction to the eighteenth century novel. London: Cambridge University Press. Barbara, B. (1987). The social law. Beijing:Foreign Language Teaching and Research Press. Eliot, G. (1994). The mill on the floss. London: Penguin Books Ltd.. Gordon, S. H. (1970). The George Eliot letters. New York: Yale University Press. Harry, B. (1998). The Victorian age of literature. Longman: York Press. Karen, P. (1994). The critical response to George Eliot. California: Greenwood Press. Kerry, M., \& Palgrave, M. (1991). George Eliot: A literary life. London: Macmillan Press Ltd.. Margaret, F. (1999). Women in the nineteenth century. Beijing: Foreign Language Teaching and Research Press. Raman, S. (2004). A reader's guide to contemporary literary theory. Beijing: Foreign Language Teaching and Research Press. 